\author{
DOI 10.31558/2307-2318.2021.4.3 \\ УДК 339.92 \\ JEL: O18, O19, N70, F10, R12
}

Мережко B.M.,

Директор Департаменту міжнародного співробітництва та регіонального розвитку

Вінницької обласної державної адміністрації,

ums@vin.gov.ua

\title{
ТЕНДЕНЦІЇ РОЗВИТКУ ЗОВНІШНЬОТОРГОВЕЛЬНОЇ ДІЯЛЬНОСТІ ВІННИЦЬКОЇ ОБЛАСТІ
}

У роботі проводиться аналіз тенденцій розвитку зовнішньоторговельної діяльності Вінницької області. У основі аналізу лежить дослідження динаміки показників зовнішньоторговельної діяльності Вінницької області за 2018 - 2020 роки та за перше півріччя 2021 року. Для Віннищької області характерними є висхідні тендениії зростання експорту, скорочення імпорту товарів та послуг, позитивне сальдо зовнішньоторговельного обороту. У дослідженні було виявлено, щзо імпорт товарів забезпечує наповнення ринку Вінницької області дефіцитними товарами; доступ до дешевих та якісних готових виробів, сировинних матеріалів, вузлів та комплектуючих деталей. Серед найбільш значних експортерів-партнерів Вінницької області у 2020 рочі були Китай (13,1\% загальних обсягів експорту), Польща - 9,8\%, Індї - 6,1\% та Румунія - 5,2\%. Відмінність динаміки експорту та імпорту у тому, щзо ринки експортних потоків щуорічно змінюються в залежності від кон'юнктури ринків товарів, а ринки імпорту товарів більш стабільні і протягом 2018-2020 років Німеччина, Польща, Китай, США та Румунія зберегли свої позиції в рейтингу країнімпортерів. Суб'єкти господарювання Віннищького регіону найбільше експортують продукцію тваринництва та рослинництва, продукти харчової промисловості. Така товарна структура експорту обумовлена потужним потенціалом регіону в галузі АПК. У дослідженні було відзначено, щуо скорочення імпорту наземного транспорту у 2020 рочі, а також електричних та механічних машин у 2019-2020 роках не $\epsilon$ наслідком розширення вітчизняного високотехнологічного виробництва, а лише засвідчує вразливість економіки держави і області до зовнішніх впливів.

Ключові слова: зовнішньоекономічна діяльність, експорт, імпорт, Вінницька область, зовнішньоторговельна діяльність, міжнародна конкурентоспроможність регіону.

Табл. - 13, Літ. -8.

Постановка проблеми. Міжнародні економічні зв'язки є важливим фактором, що впливає на динаміку національного доходу, стан науково-технічного прогресу, рівень i напрямок господарського розвитку країни та іiі регіонів. Від ступеня залучення країни в міжнародні зв'язки та міжнародний поділ праці, іiі зовнішньої активності залежать можливості найбільш раціонального використання потенціалу території, отримання досягнень світової науки, трансферту передових технологій, залучення іноземних інвестицій. Зовнішньоекономічна діяльність $є$ важливим фактором сприяння соціальноекономічному розвитку Вінницької області. Для подальшого розвитку регіону важливим $\epsilon$ аналіз сучасного стану справ у сфері міжнародної торгівлі регіону, 
виявлення перспектив та розробка обгрунтованих пропозицій щодо зміцнення позицій на міжнародній арені.

Аналіз останніх досліджень та публікацій. У сучасній науковій літературі представлено значну кількість робіт, присвячених дослідженню проблем і перспектив зовнішньоекономічної діяльності Вінницької області. Денисюк О.М. у свої праці особливу увагу приділяв аспектам зовнішньої торгівлі Вінницької області[1]. Бурлака Н. І. відзначала важливість експортної діяльності Вінницької області [2]. Аналізу сучасного стану та шляхів розвитку зовнішньоекономічної діяльності Вінницької області присвячено працю Томчук О.В. [3]. У своєму дослідженні Красняк О.П. розглянуто перспектив зовнішньоекономічну діяльність Вінницької області у аспекті функціювання підприємств [4]. Питання підвищення міжнародної конкурентоспроможності Вінницької області в умовах євроінтеграції розглянуто в праці Савченко М.В. [5].

В цілому дослідження зовнішньоекономічної діяльності Вінницької області у вітчизняній науковій літературі представлено достатньою різноманітністю напрямків. Однак, в той же час, дана тематика в умовах трансформації міжнародних зв'язків в умовах пандемії COVID-19 набуває особливої актуальності.

Метою дослідження $\epsilon$ визначення особливостей зовнішньоторговельної діяльності Вінницької області у періоді 2018 - 2021 років.

Виклад основного матеріалу. Впродовж останніх років підприємства Вінниччини суттєво розширювали зовнішньоторговельні зв'язки із господарюючими суб'єктами 3 інших країн. Зокрема, у 2010 році було налагоджено співпрацю із суб'єктами господарювання із 100 країн світу, у 2018 році - із 138, у 2019 році - із 148, у 2020 році - із 145, за 6 місяців 2021 року - із 121 країною [6].

За останні роки у загальній структурі зовнішньої торгівлі понад 90\% (у 2018 році - 93,5\%, у 2019 році - 92,6\%, у 2020 році - 89,5\%) займають товари, а решту - послуги.

Виходячи із інформації, якою володіє Департамент, здійснено аналіз показників зовнішньоторговельного обороту, експорту та імпорту товарів, їх географічної та товарної структури.

У таблиці 1 наведено динаміку зовнішньоторговельного обороту товарів та динаміка його зростання (зниження) за 2018-2020 роки та першому півріччі 2021 року.

Таблиця 1

Зовнішньоторговельний оборот товарів та динаміка його зростання (зниження) за 2018-першій половині 2021 рр., у млн. дол.США [6]

\begin{tabular}{|c|c|c|c|c|c|c|c|}
\hline $\begin{array}{c}\mathbf{2 0 1 8} \\
\text { рік }\end{array}$ & $\begin{array}{c}\text { у \% до } \\
2017 \\
\text { року }\end{array}$ & $\begin{array}{c}\mathbf{2 0 1 9} \\
\text { рік }\end{array}$ & $\begin{array}{c}\text { у \% до } \\
2018 \text { року }\end{array}$ & $\begin{array}{c}\mathbf{2 0 2 0} \\
\text { рік }\end{array}$ & $\begin{array}{c}\text { у \% до } \\
2019 \\
\text { року }\end{array}$ & $\begin{array}{c}\text { 6 місяців } \\
2021 \text { року }\end{array}$ & $\begin{array}{c}\text { у \% до } \\
\text { б місяців } \\
2020 \text { року }\end{array}$ \\
\hline $\mathbf{1 9 9 2 , 5}$ & 122,6 & $\mathbf{2 0 8 6 , 9}$ & 104,7 & $\mathbf{1 9 3 4 , 9}$ & 92,7 & 822,7 & 81,7 \\
\hline
\end{tabular}

Для Вінницької області характерними є висхідні тенденції зростання експорту, скорочення імпорту товарів та послуг, позитивне сальдо зовнішньоторговельного обороту. Проте, станом за 2020 рік відбулося зменшення обсягів експорту на 5,3\% (по Україні спад склав $1,7 \%)$.

У таблиці 2 наведено динаміку об’ємів експорту товарів за 2018-2020 роки та першому півріччі 2021 року. 
Таблиця 2

Динаміка об’ємів експорту товарів Вінницької області у 2018-першій половині 2021 рр., у млн. дол.США [6]

\begin{tabular}{|c|c|c|c|c|c|c|c|}
\hline $\begin{array}{c}\mathbf{2 0 1 8} \\
\text { рік }\end{array}$ & $\begin{array}{c}\text { у \% до } \\
2017 \\
\text { року }\end{array}$ & $\begin{array}{c}\mathbf{2 0 1 9} \\
\text { рік }\end{array}$ & $\begin{array}{c}\text { у \% до } \\
2018 \text { року }\end{array}$ & $\begin{array}{c}\mathbf{2 0 2 0} \\
\text { рік }\end{array}$ & $\begin{array}{c}\text { у \% до } \\
2019 \\
\text { року }\end{array}$ & $\begin{array}{c}\text { 6 місяців } \\
2021 \text { року }\end{array}$ & $\begin{array}{c}\text { у \% до досяців } \\
2020 \text { року }\end{array}$ \\
\hline $\mathbf{1 4 2 9 , 5}$ & 117,4 & $\mathbf{1 4 5 5 , 5}$ & 101,8 & $\mathbf{1 3 7 7 , 9}$ & 94,7 & 510,0 & 67,6 \\
\hline
\end{tabular}

Зниження обсягів експорту розпочалося у листопаді-грудні 2020 року. У січні 2021 року обсяги експорту товарів впали порівняно з січнем 2020 року на 64,1\%. Протягом січня-червня п. р. спад поступово зменшувався. Станом за перше півріччя 2021 року обсяги експорту знизились порівняно з січнем-червнем 2020 року на 32,4\%. За поясненням Головного управління статистики у Вінницькій області, до різкого зменшення обсягу експорту призвело вибуття з Вінницької області і реєстрація на іншій території одного 3 найбільших підприємств-експортерів товарів ТОВ "Вінагрогруп” (Код СДРПОУ 39652387).

За інформацією Головного управління статистики у Вінницькій області регіон займав позиції серед областей України по рейтингу за обсягами експорту та темпами зростання/зниження експорту товарів у абсолютному показнику та на душу населення у 2018-2020 роках та першому півріччі 2021 року, що відображенs у таблиця 3 та 4 [7].

Таблиця 3

Позиція Вінницької області у рейтингу регіонів України за обсягами експорту та темпами зростання/зниження експорту товарів у абсолютному показнику [7]

\begin{tabular}{|c|c|c|c|c|c|c|c|}
\hline \multicolumn{2}{|c|}{2018 рік } & \multicolumn{2}{|c|}{2019 рік } & \multicolumn{2}{|c|}{2020 рік } & \multicolumn{2}{|c|}{6 місяців 2021 року } \\
\hline $\begin{array}{c}\text { За } \\
\text { обсягом } \\
\text { експорту }\end{array}$ & $\begin{array}{l}\text { За темпом } \\
\text { зростання } \\
\text { /зниження }\end{array}$ & $\begin{array}{c}\text { За } \\
\text { обсягом } \\
\text { експорту }\end{array}$ & $\begin{array}{l}\text { За темпом } \\
\text { зростання } \\
\text { /зниження }\end{array}$ & $\begin{array}{c}\text { За } \\
\text { обсягом } \\
\text { експорту }\end{array}$ & $\begin{array}{l}\text { За темпом } \\
\text { зростання } \\
\text { /зниження }\end{array}$ & $\begin{array}{c}\text { За } \\
\text { обсягом } \\
\text { експорту }\end{array}$ & $\begin{array}{l}\text { За темпом } \\
\text { зростання } \\
\text { /зниження }\end{array}$ \\
\hline 11 & 10 & 10 & 16 & 10 & 17 & 14 & 25 \\
\hline
\end{tabular}

Таблиця 4

Позиція Вінницької області у рейтингу регіонів України за обсягами експорту та темпами зростання/зниження експорту товарів на душу населення [7]

\begin{tabular}{|c|c|c|c|c|c|c|c|}
\hline \multicolumn{2}{|c|}{2018 рік } & \multicolumn{2}{|c|}{2019 рік } & \multicolumn{2}{|c|}{2020 рік } & \multicolumn{2}{|c|}{6 місяців 2021 року } \\
\hline $\begin{array}{c}\text { Обсяг } \\
\text { експорту }\end{array}$ & $\begin{array}{l}\text { Місце у } \\
\text { рейтинг }\end{array}$ & $\begin{array}{c}\text { Обсяг } \\
\text { експорту }\end{array}$ & $\begin{array}{l}\text { Місце у } \\
\text { рейтинг }\end{array}$ & $\begin{array}{c}\text { Обсяг } \\
\text { експорту }\end{array}$ & $\begin{array}{l}\text { Місце у } \\
\text { рейтинг }\end{array}$ & $\begin{array}{c}\text { Обсяг } \\
\text { експорту }\end{array}$ & $\begin{array}{l}\text { Місце у } \\
\text { рейтинг }\end{array}$ \\
\hline $\begin{array}{c}\text { на одну } \\
\text { особу, } \\
\text { дол.СШ } \\
\text { А }\end{array}$ & $\mathrm{y}$ & $\begin{array}{c}\text { на одну } \\
\text { особу, } \\
\text { дол.СШ } \\
\text { А }\end{array}$ & $\mathrm{y}$ & $\begin{array}{c}\text { на одну } \\
\text { особу, } \\
\text { дол.СШ } \\
\text { А }\end{array}$ & $\mathrm{y}$ & $\begin{array}{c}\text { на одну } \\
\text { особу, } \\
\text { дол.СШ } \\
\text { А }\end{array}$ & $\mathrm{y}$ \\
\hline 911,0 & 9 & 936,9 & 9 & $\mathbf{8 9 5 , 8}$ & 13 & - & - \\
\hline
\end{tabular}

Імпорт товарів забезпечує наповнення регіонального ринку дефіцитними товарами; доступ до дешевих та якісних готових виробів, сировинних матеріалів, вузлів та комплектуючих деталей. Він сприяє налагодження сталих виробничих зв'язків щодо кооперування виробництва з іноземними партнерами, впровадженню нових технологій завдяки ввезенню наукоємних товарів, підвищенню якості виробництва на території 
області. У таблиці нижче наведено динаміку об'ємів імпорту товарів Вінницької області у 2018-2020 році та першому півріччі 2021 року.

Таблиця 5 Динаміка об’ємів імпорту товарів Вінницької області у 2018-першій половині 2021

\begin{tabular}{|l|l|l|ll|l|lr|l|l|}
\hline $\mathbf{2 0 1 8}$ рік & $\begin{array}{l}\text { у \% до } \\
2017 \\
\text { року }\end{array}$ & $\mathbf{2 0 1 9}$ рік & $\begin{array}{l}\text { y \% до } \\
2018 \text { року }\end{array}$ & $\begin{array}{l}\mathbf{2 0 2 0} \\
\text { piк }\end{array}$ & $\begin{array}{l}\text { у } \% \text { до } \\
2019 \text { року }\end{array}$ & $\begin{array}{l}\text { 6 місяців } \\
2021 \\
\text { року }\end{array}$ & $\begin{array}{l}\text { у \% до } \\
\text { 6 місяців } \\
2020 \\
\text { року }\end{array}$ \\
\hline $\mathbf{5 6 3 , 0}$ & 138,3 & $\mathbf{6 3 1 , 6}$ & 112,2 & $\mathbf{5 5 7 , 0}$ & 88,2 & 312,7 & 123,9 \\
\hline
\end{tabular}

У таблиці 6 відображено найбільших торговельні партнери Вінницької області та динаміка їхньої питомої ваги у загальному експорті товарів протягом 2018 -2020 років та першому півріччі 2021 року.

Таблиця 6

Динаміка обсягів питомої ваги у загальному експорті найбільших торговельних партнерах Вінницької області [8]

\begin{tabular}{|l|l|l|l|l|}
\hline \multirow{2}{*}{$\begin{array}{l}\text { Найбільші } \\
\text { екпортери }\end{array}$} & \multicolumn{4}{|c|}{ Питома вага у загльому експорті, \% до загального експорту } \\
\cline { 2 - 5 } & $\mathbf{2 0 1 8}$ рік & $\mathbf{2 0 1 9}$ рік & $\mathbf{2 0 2 0}$ рік & $\mathbf{6}$ міс. 2021рік \\
\hline Китай & $\mathbf{7 , 9}$ & $\mathbf{1 1 , 2}$ & $\mathbf{1 3 , 1}$ & $\mathbf{1 5 , 7}$ \\
\hline Польща & $\mathbf{9 , 4}$ & $\mathbf{9 , 3}$ & $\mathbf{9 , 8}$ & $\mathbf{1 4 , 0}$ \\
\hline Румунія & 3,3 & $\mathbf{4 , 9}$ & $\mathbf{5 , 2}$ & $\mathbf{8 , 4}$ \\
\hline Туреччина & 3,7 & 4,3 & 4,0 & $\mathbf{5 , 2}$ \\
\hline Білорусь & $\mathbf{5 , 4}$ & $\mathbf{4 , 7}$ & 4,3 & $\mathbf{4 , 1}$ \\
\hline РФ & 2,7 & 3,0 & 2,7 & 4,0 \\
\hline Нідерланди & 2,1 & 4,4 & $\mathbf{4 , 9}$ & 3,7 \\
\hline Індія & $\mathbf{1 5 , 6}$ & 4,6 & $\mathbf{6 , 1}$ & 3,6 \\
\hline Сгипет & 3,3 & $\mathbf{6 , 8}$ & 3,6 & 3,6 \\
\hline Іспанія & $\mathbf{4 , 1}$ & 2,9 & 3,9 & 3,6 \\
\hline Литва & 1,7 & 1,6 & 2,2 & 3,0 \\
\hline Молдова & 2,4 & 2,5 & 2,5 & 2,8 \\
\hline $\begin{array}{l}\text { Велика } \\
\text { Британія }\end{array}$ & 1,2 & 0,9 & 0,6 & 2,7 \\
\hline Німеччина & 3,3 & 4,2 & 2,5 & 2,6 \\
\hline Італія & 3,4 & 2,6 & 3,4 & 2,0 \\
\hline
\end{tabular}

Станом за 2018 рік в експорті товарів значна доля належить Індії (15,6\% загальних обсягів експорту), Польщі - 9,4\%, Китаю - 7,9\%, Білорусі - 5,4\%, Іспанії 4,1\%, Туреччині - 3,7\%, Італії - 3,4\%, Сгипту, Німеччині та Румунії - по 3,3\%, Російській Федерації - 2,7\%, Саудівській Аравії і Молдові - по 2,4\% та Нідерландам $2,1 \%$.

Станом за 2019 рік в експорті товарів значна доля належить Китаю (11,2\% загальних обсягів експорту), Польщі - 9,3\%, Сгипту - 6,8\%, Румунії - 4,9\%, Білорусі 4,7\%, Індії - 4,6\%, Нідерландам - 4,4\%, Туреччині - 4,3\%, Німеччині $-4,2 \%$ та Російській Федерації-3,0\%.

Станом за 2020 рік в експорті товарів значна доля належить Китаю $(13,1 \%$ загальних обсягів експорту), Польщі - 9,8\%, Індії - 6,1\%, Румунії - 5,2\%, Нідерландам 
- 4,9\%, Білорусі - 4,3\%, Туреччині - 4,0\%, Іспанії - 3,9\%, Сгипту - 3,6\%, Італії - 3,4\%, Російській Федерації - 2,7\%, Німеччині та Молдові - по 2,5\%, Литві - 2,2\% та Малайзії $-2,0 \%$.

У таблиці 7 відображено найбільших торговельні партнери Вінницької області та динаміка їхньої питомої ваги у загальному імпорті товарів протягом 2018-2020 років та першому півріччі 2021 року.

Таблиця 7

Динаміка обсягів питомої ваги у загальному імпорті найбільших торговельних партнерах Вінницької області [8]

\begin{tabular}{|l|c|c|c|c|}
\hline \multirow{2}{*}{$\begin{array}{l}\text { Найбільші } \\
\text { імпортери }\end{array}$} & \multicolumn{4}{|c|}{ Питома вага узальному імпорті, $\mathbf{\%}$ до загального імпорту } \\
\cline { 2 - 5 } & $\mathbf{2 0 1 8}$ рік & $\mathbf{2 0 1 9}$ рік & $\mathbf{2 0 2 0}$ рік & $\mathbf{6}$ міс. 2021рік \\
\hline Німеччина & $\mathbf{1 3 , 1}$ & $\mathbf{1 0 , 6}$ & $\mathbf{1 2 , 2}$ & $\mathbf{1 6 , 3}$ \\
\hline Польща & $\mathbf{9 , 4}$ & $\mathbf{1 1 , 9}$ & $\mathbf{1 3 , 3}$ & $\mathbf{1 3 , 4}$ \\
\hline Китай & $\mathbf{2 0 , 2}$ & $\mathbf{2 1 , 2}$ & $\mathbf{1 4 , 1}$ & $\mathbf{1 2 , 0}$ \\
\hline США & $\mathbf{6 , 6}$ & $\mathbf{6 , 0}$ & $\mathbf{7 , 4}$ & $\mathbf{9 , 4}$ \\
\hline Румунія & $\mathbf{5 , 7}$ & $\mathbf{5 , 7}$ & $\mathbf{6 , 3}$ & $\mathbf{7 , 7}$ \\
\hline Туреччина & 4,8 & 3,7 & 4,9 & 3,6 \\
\hline Італія & 4,1 & 3,6 & 3,7 & 3,4 \\
\hline Білорусь & 5,0 & 3,9 & 3,9 & 3,1 \\
\hline Австрія & 1,9 & 2,0 & 2,7 & 2,9 \\
\hline РФ & 3,8 & 3,2 & 3,5 & 2,7 \\
\hline Нідерланди & 2,9 & 2,2 & 2,2 & 2,4 \\
\hline Сербія & 2,6 & 4,2 & 3,9 & 2,1 \\
\hline Чехія & 3,3 & 2,6 & 1,7 & 1,1 \\
\hline Іспанія & 1,4 & 1,7 & 2,0 & 1,1 \\
\hline
\end{tabular}

Відмінність динаміки експорту та імпорту у тому, що ринки експортних потоків щорічно змінюються в залежності від кон'юнктури ринків товарів, а ринки імпорту товарів більш стабільні і протягом 2018-2020 років Німеччина, Польща, Китай, США та Румунія зберегли свої позиції в рейтингу країн-імпортерів. У таблиці 8 наведено динаміку змін у географічній структурі зовнішньої торгівлі товарами у Вінницькій області у 2018-2020 роках.

Таблиця 8

Динаміка географічної структури зовнішньої торгівлі товарами у Вінницькій області (2018-2020рр.), (млн.дол. США) [8]

\begin{tabular}{|c|c|c|c|c|c|c|c|c|c|}
\hline \multicolumn{10}{|c|}{ Експорт } \\
\hline Усього & $\begin{array}{c}\text { Країни } \\
\text { СНД }\end{array}$ & $\begin{array}{c}\text { Інші } \\
\text { країни } \\
\text { світу }\end{array}$ & Свропа & $\begin{array}{c}\text { Країни } \\
\text { СС (28) }\end{array}$ & Азія & Африка & Америка & $\begin{array}{c}\text { Австралія } \\
\text { і Океанія }\end{array}$ \\
\hline 2018 & 1429,5 & 190,5 & 1238,8 & 502,7 & 499,1 & 619,1 & 99,0 & 16,5 & 1,5 \\
\hline 2019 & 1455,5 & - & - & 544,8 & 542,9 & 521,0 & 173,6 & 19,4 & 4,8 \\
\hline 2020 & 1377,9 & - & - & 547,3 & 538,3 & 546,0 & 95,0 & 26,0 & 0,7 \\
\hline \multicolumn{8}{|c|}{ Імпорт } \\
\hline 2018 & 563,0 & 55,6 & 507,5 & 288,7 & 270,5 & 167,5 & 5,0 & 46,3 & 0,0 \\
\hline 2019 & 631,6 & - & - & 338,7 & 309,1 & 190,9 & 6,3 & 47,1 & 0,3 \\
\hline 2020 & 557,0 & - & - & 319,8 & 288,7 & 132,0 & 5,9 & 50,6 & 0,0 \\
\hline
\end{tabular}


Таким чином, країни $Є С(28)$ та Азії є найбільшими торговельними партнерами області. Питома вага цих країн у зовнішньоторговельному обороті товарів майже однакова, коливання незначні і відбуваються в залежності від кон'юнктури ринку.

У таблиці 9 відображено структурні зміни у експорті Вінницького регіону у 2018 2021 роках.

Таблиця 9

Динаміка найважливіших товарних груп у структурі експорту товарів за 2018першій половині 2021 рр. (у \% до загального обсягу експорту товарів) [8]

\begin{tabular}{|l|c|c|c|c|}
\hline & 2018 рік & 2019 рік & 2020 рік & $\begin{array}{c}\text { I півріччя } \\
2021 \text { рік }\end{array}$ \\
\hline $\begin{array}{l}\text { I. Живі тварини; продукти } \\
\text { тваринного походження }\end{array}$ & 5,6 & 8,6 & 5,3 & 7,5 \\
\hline $\begin{array}{l}\text { II. Продукти рослинного } \\
\text { походження }\end{array}$ & $\mathbf{2 4 , 8}$ & $\mathbf{3 3 , 2}$ & $\mathbf{2 7 , 4}$ & $\mathbf{2 5 , 0}$ \\
\hline $\begin{array}{l}\text { III. Жири та олії } \\
\text { тваринного або рослинного } \\
\text { походження }\end{array}$ & $\mathbf{3 4 , 6}$ & $\mathbf{2 1 , 5}$ & $\mathbf{2 9 , 5}$ & $\mathbf{1 8 , 5}$ \\
\hline IV. Готові харчові продукти & $\mathbf{1 4 , 7}$ & $\mathbf{1 4 , 3}$ & $\mathbf{1 4 , 9}$ & $\mathbf{1 2 , 8}$ \\
\hline V. Мінеральні продукти & 2,2 & 2,2 & 2,0 & 3,1 \\
\hline $\begin{array}{l}\text { VI. Продукція хімічної та } \\
\text { пов'язаних з нею галузей } \\
\text { промисловості }\end{array}$ & 1,5 & 1,8 & 1,9 & 2,8 \\
\hline IХ. Деревина і вироби із неї & 7,8 & 8,1 & 8,0 & 12,9 \\
\hline $\begin{array}{l}\text { ХІ. Текстильні матеріали та } \\
\text { вироби }\end{array}$ & 2,3 & 2,1 & 1,5 & 1,2 \\
\hline $\begin{array}{l}\text { ХV. Недорогоцінні метали та } \\
\text { вироби з них }\end{array}$ & 1,6 & 1,5 & 1,8 & 2,5 \\
\hline $\begin{array}{l}\text { ХУІ. Машини, обладнання та } \\
\text { механізми; електротехнічне } \\
\text { обладнання }\end{array}$ & 3,6 & 5,3 & 5,9 & 11,1 \\
\hline Iнші товарні групи & 1,3 & 1,4 & 1,8 & 2,6 \\
\hline
\end{tabular}

Суб’єкти господарювання Вінницького регіону найбільше експортують продукцію тваринництва та рослинництва, продукти харчової промисловості. Така товарна структура експорту обумовлена потужним потенціалом регіону в галузі АПК. Проте, як показав аналіз динаміки питомої ваги товарних груп у структурі зовнішньої торгівлі, за підсумками I кварталу 2021 року у обсягах експорту збільшується частка деревини та виробів з неї, продукції машинобудування, живих тварин, мінеральних продуктів, товарів хімічної промисловості та недорогоцінних металів.

При порівнянні динаміки питомої ваги основних груп товарів вирізняються окремі групи, по яких відбулося суттєве зниження показників. Поглиблений аналіз експорту окремих товарів показав, що спад відбувся наприкінці 2020 року за рахунок зменшення експортних поставок жирів та олії (на 61,6\%), продукції рослинного походження (на 84,4\%), а саме: зернових культур (11,2\% до минулого року) та продукції борошномельно-круп'яної промисловості $(50,6 \%)$; продуктів тваринного походження (на 85,0\%), з них: м'яса та їстівних субпродуктів (4,2\% до минулого року); готових харчових продуктів (на $56,7 \%$ ), 3 них: залишків і відходів харчової 
промисловості (23,0\%). За цими товарними позиціями обсяги експорту у вартісних величинах зменшилися на 87,6\% (на 121,1 млн.дол.США).

Найбільшого спаду обсягів експорту у січні 2021 року зазнали такі товари, як олія, зернові культури, м'ясо та макуха.

До зменшення обсягів експорту олії та зернових, за поясненням Головного управління статистики у Вінницькій області, призвело вибуття з Вінницької області і реєстрація на іншій території одного з найбільших підприємств-експортерів товарів ТОВ ”Вінагрогруп” (Код ЄДРПОУ 39652387).

Крім того, поставки м'яса та субпродуктів зменшились через пташиний грип, оскільки Свросоюз вводив заборону на поставки української курятини.

Щодо зернових, то у 2020/2021 році через складні кліматичні умови (різкий перепад температур, зміну засухи на грозові дощі) був менший врожай і на кінець року були менші перехідні залишки товарного зерна.

Внаслідок цих та інших причин скоротилися кількісні і вартісні обсяги продажу основних експортних позицій агропродукції.

Порівняно з січнем 2021 року у січні-червні 2021 року спад експорту товарів зменшився на 31,7\% (від 64,1\% за січень до 32,4\% за I квартал 2021 року). Зменшення обсягів експорту товарів відбулось, в основному, за рахунок зменшення експортних поставок:

- жирів та олії тваринного або рослинного походження (на 63,0\%);

- текстильних матеріалів та текстильних виробів (на 45,4\%), а саме: одягу та додаткових речей для одягу, текстильних $(47,1 \%$ до відповідного періоду минулого року);

- готових харчових продуктів (на 42,6\%), з них: залишків і відходів харчової промисловості (44,5\% до відповідного періоду минулого року);

- продукції рослинного походження (на $35,9 \%$ ), а саме: зернових культур $(62,0 \%$ до відповідного періоду минулого року) та продукції борошномельно-круп'яної промисловості $(59,7 \%)$.

Таблиця 10

Динаміка експорту окремих товарів, по яких відбувся значний спад вінницьких поставок за межі області у січні-червні 2021 року (тис.дол.США) [8]

\begin{tabular}{|l|c|c|c|}
\hline & $\begin{array}{c}\text { I півріччя } \\
2020 \text { року }\end{array}$ & $\begin{array}{c}\text { I півріччя } \\
2021 \text { року }\end{array}$ & $\begin{array}{c}\text { Динаміка } \\
\text { Зниження } \\
\text { експорту товарів } \\
\text { окремих груп }\end{array}$ \\
\hline $\begin{array}{l}\text { II. Продукти рослинного походження: } \\
\text { - зернові культури; } \\
\text { - продукція борошномельно-круп'яної } \\
\text { промисловості }\end{array}$ & $\begin{array}{c}177649,4 \\
9264,5\end{array}$ & $\begin{array}{c}110071,7 \\
5533,0\end{array}$ & $\begin{array}{c}67577,7 \\
3731,5\end{array}$ \\
\hline $\begin{array}{l}\text { III. Жири та олії тваринного або } \\
\text { рослинного походження }\end{array}$ & 254564,2 & 94145,7 & 160418,5 \\
\hline $\begin{array}{l}\text { IV. Готові харчові продукти: } \\
\text {-залишки та відходи харчової } \\
\text { промисловості }\end{array}$ & 77062,7 & 34325,1 & 42737,6 \\
\hline $\begin{array}{l}\text { ХІ. Текстильні матеріали та вироби: } \\
\text {-одяг та додаткові речі для одягу }\end{array}$ & 10406,4 & 4901,1 & 5505,3 \\
\hline Всього & $\mathbf{5 2 8 9 4 7 , 2}$ & $\mathbf{2 4 8 9 7 6 , 6}$ & $\mathbf{2 7 9 9 7 0 , 6}$ \\
\hline
\end{tabular}


У таблиці вище відображено основні групи товарів, по яких відбувся спад станом за І півріччя 2021 року на 53,0\% (280,0 млн.дол.США). Проте найбільший спад протягом 2021 року продовжують спричиняти такі товари, як олія, зернові культури та макуха. Проте, ці товари відносяться до сезонного експорту, тому у перехідний період експорт залежить від перехідних залишків, кон'юнктури ринку та врожаю за попередній маркетинговий рік.

Крім того, варто відмітити, що серед експортованих товарів $є$ такі, які можуть стати драйверами вінницького експорту, так як їхня питома вага стабільно зростає. До них належать: електротехнічне обладнання, продукція хімічної промисловості, недорогоцінні метали та вироби з них, деревина та вироби з неї.

Так, в загальному обсязі товарів, які імпортували вінницькі підприємства, найбільша питома вага припадає на машини, обладнання та електротехнічне обладнання; засоби наземного транспорту; продукцію хімічної промисловості. Ці групи товарів мають тенденцію до незначних коливань, проте протягом 2018-2020 років і в I півріччі 2021 року займають основні позиції у рейтингу найбільш імпортованих товарів.

Імпортуються на Вінниччину значна кількість машин сільськогосподарського призначення, комбайни зернозбиральні, трактори, автонавантажувачі; автобуси, автомобілі легкові, вантажні та спеціальні. Область також імпортує значну кількість добрив. Пандемія вплинула на збільшення імпорту медикаментів, приладів і апаратів оптичних та фотографічних. Одночасно зменшився імпорт товарів, на які змінився попит через карантинні обмеження: недорогоцінні метали та вироби 3 них, текстильні матеріали та вироби. Так, у підприємств легкої промисловості області, які донедавна успішно працювали по схемі «давальницької сировини», значно зменшилась кількість замовлень на виготовлення одягу для роботи в офісах (костюмів, спідниць, брюк, сорочок, блуз та пальто): у 2018 році було експортовано одягу текстильного на 29,7 млн.дол, у 2019 році - на 27,3 млн.дол, у 2020 році - на 18,3 млн.дол.

Таблиця 11

Динаміка структурних змін у експорті товарів Вінницької області товарів за 2018першій половині 2021 рр. (тис.дол.США) (питома вага, у \% до загального обсягу імпорту товарів) [8]

\begin{tabular}{|c|c|c|c|c|}
\hline & 2018 рік & 2019 рік & 2020 рік & $\begin{array}{c}\text { I } \\
\text { півріччя } \\
2021 \\
\text { року } \\
\end{array}$ \\
\hline $\begin{array}{l}\text { I Живі тварини, продукти } \\
\text { тваринного походження }\end{array}$ & 1,1 & 1,5 & 1,1 & 0,5 \\
\hline $\begin{array}{l}\text { II. Продукти } \\
\text { походження }\end{array}$ & 2,9 & 2,4 & 3,2 & 2,7 \\
\hline III. Жири та олії & 1,7 & 2,2 & 1,1 & 0,5 \\
\hline IV.Готові харчові продукти & 4,1 & 3,4 & 4,5 & 4,5 \\
\hline V. Мінеральні продукти & 4,8 & 2,8 & 2,1 & 1,4 \\
\hline $\begin{array}{l}\text { VI. Продукція хімічної та } \\
\text { пов'язаних } 3 \text { нею галузей } \\
\text { промисловості }\end{array}$ & 12,5 & 14,3 & 16,6 & 15,0 \\
\hline \begin{tabular}{|lc} 
VII.Полімерні & матеріали, \\
пластмаси та вироби 3 них
\end{tabular} & 6,4 & 6,8 & 7,3 & 7,7 \\
\hline
\end{tabular}




\begin{tabular}{|l|c|c|c|c|}
\hline IХ. Деревина і вироби із неї & 6,3 & 4,6 & 5,3 & 6,3 \\
\hline Х. Маса з деревини & 0,1 & 1,2 & 1,4 & 1,6 \\
\hline $\begin{array}{l}\text { ХІ. Текстильні матеріали та } \\
\text { вироби }\end{array}$ & 5,2 & 4,4 & 4,0 & 3,4 \\
\hline $\begin{array}{l}\text { ХІІІ. Вироби з каменю, гіпсу, } \\
\text { цементу }\end{array}$ & 0,1 & 1,0 & 1,3 & 1,3 \\
\hline $\begin{array}{l}\text { ХV. Недорогоцінні метали та } \\
\text { вироби з них }\end{array}$ & 10,8 & 10,1 & 9,5 & 7,5 \\
\hline $\begin{array}{l}\text { ХVI. Машини, обладнання та } \\
\text { механізми; електротехнічне } \\
\text { обладнання }\end{array}$ & $\mathbf{2 8 , 6}$ & $\mathbf{2 7 , 3}$ & $\mathbf{2 2 , 1}$ & $\mathbf{2 6 , 3}$ \\
\hline $\begin{array}{l}\text { ХVII. Засоби наземного } \\
\text { транспорту }\end{array}$ & $\mathbf{1 0 , 7}$ & $\mathbf{1 4 , 5}$ & $\mathbf{1 3 , 8}$ & $\mathbf{1 7 , 1}$ \\
\hline $\begin{array}{l}\text { ХУІІІПрилади оптичні, } \\
\text { фотографічні }\end{array}$ & 1,2 & 1,4 & 3,2 & 2,6 \\
\hline $\begin{array}{l}\text { ХХ. Різні промислові товари } \\
\text { Інші групи }\end{array}$ & 2,8 & 0,6 & 2,8 & 0,9 \\
\hline
\end{tabular}

Водночас, скорочення імпорту наземного транспорту у 2020 році, а також електричних та механічних машин у 2019-2020 роках не $є$ наслідком розширення вітчизняного високотехнологічного виробництва, а лише засвідчує вразливість економіки держави і області до зовнішніх впливів. Крім того, за низької інвестиційноінноваційної спроможності вітчизняних підприємств зниження імпорту високотехнічного i-технологічного обладнання може стати загрозою їх технологічного переоснащення. Дані проведеного аналізу показали, що для Вінницького регіону $\epsilon$ характерним дефіцит механічних та електричних машин, продукції хімічної промисловості. А тому суб'єкти господарювання області повинні бути переорієнтовані на виробництво вітчизняної продукції, що дозволить замінити аналогічну імпортну за згаданими видами.

Серед партнерів Вінницької області чільне місце посідають країни СС, розширення співпраці з якими є особливо актуальним за умов погіршення зв'язків із Росією. 16 вересня 2020 року минуло шість років від часу ратифікації Угоди про асоціацію між Україною та СС. Завершився п'ятий рік дії ії економічної частини про зону вільної торгівлі, яка набрала чинності з початку 2016-го.

На сьогодні можна констатувати чітке визначення стратегічного вектору зовнішньої політики України - європейська інтеграція, яка стала офіційним пріоритетом національної політики.

До складу Європейського Союзу входять найбільш розвинуті європейські держави, які активно здійснюють торгівлю на світовому ринку i $\epsilon$ привабливими економічними партнерами підприємств Вінниччини.

Серед партнерів Вінницької області чільне місце посідають країни ЄС, розширення співпраці з якими $є$ особливо актуальним за умов погіршення зв'язків із Росією. В останні роки торговельно-економічні відносини між Вінниччиною та країнами ЄС суттєво поглибилися.

За інформацією Головного управління статистики у Вінницькій області, динаміка зовнішньої торгівлі вінницьких товарів з країнами СС у 2018-2020 роках та I півріччі 2021 року представлена у таблицях 12 та 13. 
Таблиця 12

Динаміка експорту та імпорту Вінницької області з країнами СС у 2018-першій половині 2021 рр. [6]

\begin{tabular}{|c|c|c|c|c|c|c|c|c|}
\hline & \multicolumn{2}{|c|}{2018 рік } & \multicolumn{2}{|c|}{2019 рік } & \multicolumn{2}{|c|}{2020 рік } & \multicolumn{2}{|c|}{ І півріччя 2021 рік } \\
\hline & $\begin{array}{c}\text { млн.дол. } \\
\text { США }\end{array}$ & $\begin{array}{l}\text { у \% до } \\
2017 \text { p. }\end{array}$ & $\begin{array}{c}\text { млн.дол. } \\
\text { США }\end{array}$ & $\begin{array}{l}\text { у \% до } \\
2018 p .\end{array}$ & $\begin{array}{c}\text { млн.дол. } \\
\text { США }\end{array}$ & $\begin{array}{l}\text { у \% до } \\
2019 p .\end{array}$ & $\begin{array}{c}\text { млн.дол. } \\
\text { США. }\end{array}$ & $\begin{array}{l}\text { у \% до } \\
\text { I півріччя } \\
\text { 2020p. }\end{array}$ \\
\hline Експорт & 499,1 & 112,1 & 542,9 & 108,8 & 546,1 & 100,6 & 220,3 & 78,4 \\
\hline Імпорт & 270,5 & 127,9 & 309,0 & 114,2 & 295,0 & 95,4 & 175,6 & 138,1 \\
\hline
\end{tabular}

Таблиця 13

Питома вага експорту/імпорту товарів Вінницької області до/з країн ЄС від загального обсягу, у \% у 2018-першій половині 2021 рр [6]

\begin{tabular}{|l|l|l|l|ll|}
\hline & \multicolumn{1}{|c|}{2018} & \multicolumn{1}{|c|}{2019} & \multicolumn{1}{c|}{2020} & I півріччя 2021 \\
\hline Експорт & 34,9 & 37,3 & 39,6 & 43,2 \\
\hline Імпорт & 48,0 & 48,9 & 53,0 & 56,1 & \\
\hline
\end{tabular}

Станом за січень-грудень 2020 року провідне місце в зовнішній торгівлі товарами серед країн СС займають такі країни, як Польща (134,6 млн.дол.), Румунія (71,2 млн.дол.), Нідерланди (67,2 млн.дол.), Іспанія (54,4 млн.дол.), Італія (46,8 млн.дол.), Німеччина (35,1 млн.дол.), Литва (29,9 млн.дол.), Австрія (21,6 млн.дол.), Франція (18,6 млн.дол.), Бельгія (17,6 млн.дол.).

Аналізуючи товарну структуру експорту з країнами Свросоюзу, слід зазначити, що особливим попитом в країнах Європейської співдружності користуються деревина і вироби 3 деревини, продукти рослинного походження, машини, обладнання та механізми, електротехнічне обладнання, жири та олії, готові харчові продукти, текстильні матеріали та текстильні вироби, живі тварини, продукти тваринного походження, продукція хімічної промисловості та недорогоцінні метали та вироби 3 них.

Основними статтями імпортних надходжень області з країн ЄС є машини, обладнання та механізми, електротехнічне обладнання, продукція хімічної промисловості, засоби наземного транспорту, деревина і вироби 3 неї, полімерні матеріали, пластмаси та вироби з них, готові харчові продукти, недорогоцінні метали та вироби 3 них, текстильні матеріали та текстильні вироби, маса 3 деревини або інших волокнистих целюлозних матеріалів, продукти рослинного походження та різні промислові товари.

У 2020 році Україні вдалося повністю вичерпати квоти на безмитні поставки до країн Євросоюзу меду, яблучного і виноградного соків, цукру, ячмінної крупи i борошна, консервованих томатів, обробленого крохмалю, кукурудзи, м'яса птиці, яєць, обробленої продукції з зернових та крохмалю. На відміну від 2019 року, квоти на експорт пшениці і вершкового масла закрити не вдалося.

Протягом січня 2021 року українські компанії вже в повному обсязі використали квоти на мед та яблучний і виноградний соки.

Варто відмітити, що український експорт до $\mathrm{CC}$, в тому числі і вінницький, поки що має надто велику частку сировини й напівфабрикатів із низькою доданою вартістю. Однак це проблема не нашої торгівлі з СС, а структури економіки й експорту України 
загалом. До того ж зміна товарної структури торгівлі з СС і тенденції загалом свідчать, що європейська інтеграція якраз допомагає долати сировинність нашої економіки. Крім того, саме місткий і платоспроможний ринок ЄС є найкращим стимулом для розвитку українського малого й середнього бізнесу, який концентрується на виготовленні готової продукції з вищою доданою вартістю.

Таким чином, світові ринки, зокрема ринки країн $\mathrm{CC}, \epsilon$ досить привабливими для вітчизняних підприємств не лише з точки зору обсягу платоспроможного попиту, але й з точки зору стимулів вдосконалення матеріально-технічної, виробничої бази, підвищення конкурентоздатності товарів i послуг через дотримання високих європейських стандартів щодо якості виробництва та реалізації української продукції.

Зовнішньоторговельний оборот послуг порівняно незначний, проте має стійку тенденцію до зростання. У 2018 році він складав 6,5\%, у 2019 році - 7,4\%, у 2020 році - 10,5\%, станом за I півріччі 2021 року - 11,3\% до загального зовнішньоторговельного обороту товарів і послуг.

Станом за січень-червень 2021 року зовнішньоторговельні операції послугами суб'єкти господарювання області здійснювали 3 партнерами із 94 країн світу. Аналізуючи географічну структуру зовнішньої торгівлі послугами слід відмітити, що найбільша доля експорту послуг належить Ізраїлю (40,5\% загальних обсягів експорту), Мальті (15,6\%), Румунії (10,1\%), США (6,4\%), Естонії (4,1\%), Німеччині $(3,3 \%)$, Російській Федерації (1,7\%), Індії, Люксембургу та Угорщині. В імпортних надходженнях найбільша частка припадала на такі країни, як Польща (27,4\% загальних обсягів імпорту), Сполучене Королівство Великої Британії та Північної Ірландії $(14,6 \%)$, Чехія (10,7\%), Німеччина (9,3\%), Російська Федерація $(3,7 \%)$, Швеція $(3,6 \%)$, Франція (3,3\%), Австрія (3,1\%), Нідерланди $(2,8 \%)$, Литва $(2,1 \%)$, Естонія $(1,4 \%)$, США (1,3\%), Іспанія та Кіпр.

У загальній структурі експорту послуг основою залишаються послуги у сфері телекомунікації, комп’ютерні та інформаційні послуги, їх частка становить 74,4\%. Саме цей вид послуг найбільше впливає на формування позитивного сальдо $(87,8 \%$ від загального сальдо). Крім того, в значних обсягах надавались послуги 3 переробки матеріальних ресурсів та послуги пов'язані з подорожами, обсяги яких становлять, відповідно, 12,8 млн.дол. і 6,5 млн.дол.

У структурі імпорту найбільша доля належить діловим послугам (22,0\%), послугам, пов'язаним 3 фінансовою діяльністю (20,6\%), роялті та іншим послугам, пов'язаним 3 використанням інтелектуальної власності $(17,1 \%)$, послугам у сфері телекомунікації, комп'ютерним та інформаційним послугам (14,9\%) та транспортним послугам (5,4\%). Крім того, великим попитом у суб'єктів підприємницької діяльності області користувались послуги 3 ремонту і технічного обслуговування, послуги 3 будівництва та послуги пов'язані з подорожами.

Зовнішньоторговельний оборот послуг країн $\mathrm{CC}$ становить 48,7 млн.дол. (46,5\% загальнообласних обсягів послуг), у тому числі експорт - 36,2 млн.дол. та імпорт - 12,5 млн.дол. Основними послугами, що надавались нерезидентам країн СС, стали послуги у сфері телекомунікації, комп'ютерні та інформаційні послуги (63,7\% від обсягу надаваних послуг до країн СС), послуги з переробки матеріальних ресурсів (30,4\%), ділові послуги (2,0\%), ділові та транспортні послуги (по 2,0\%).

Отримували від них суб'єкти підприємницької діяльності області ділові послуги (25,4\% від обсягу отриманих послуг з країн СС), послуги у сфері телекомунікації, комп'ютерні та інформаційні послуги $(19,1 \%)$, роялті та інші послуги, пов'язані 3 використанням інтелектуальної власності $(17,8 \%)$, послуги пов'язані 3 фінансовою 
діяльністю (7,1\%), транспортні $(6,5 \%)$, послуги з ремонту та технічного обслуговування $(3,4 \%)$ та послуги, пов'язані з подорожами $(2,2 \%)$.

Висновки. У зв'язку з військовими діями на сході України частково відбулася зміна основних країн-партнерів, яким підприємства області постачали продукцію машинобудування, готові харчові продукти, текстильні та трикотажні вироби. Протягом останніх років, починаючи 32014 року, відбувається переорієнтація торговельних потоків із країн колишнього СРСР переважно на ринки ЄС та країн Азії, розширення співпраці з якими є особливо актуальним за умов погіршення зв'язків із Росією та Республікою Білорусь.

Крім того, на скорочення споживання товарів довгострокового попиту значно вплинула пандемія, що також негативно позначилось на роботі підприємств легкої промисловості області, які працювали по схемі «давальницької сировини».

Суб'єкти господарювання Вінницького регіону найбільше експортують продукцію тваринництва та рослинництва, деревину та вироби 3 неї, електричне устаткування, продукцію хімічної промисловості. Така товарна структура експорту зумовлена потужним потенціалом регіону в галузі АПК та інвесторами, які створюють робочі місця у регіоні.

Проте товарна структура експорту потребує удосконалення шляхом підвищення ступеня обробки сировинних ресурсів, збільшення частки готової продукції. Тому важливим $є$ також той фактор, що поступово відбувається перехід від сировинної структури експорту до експорту товарів із доданою вартістю. Так, питома вага такого експорту хоч незначними темпами, проте постійно збільшується. Протягом останніх років змінюється і структура експорту таких товарів. Сьогодні більшу частину експортної продукції (більше 60,0\%) складають товари і вироби промислових підприємств області $з$ доданою вартістю. Основу товарної структури експорту товарів із доданою вартістю складають олія, готові харчові продукти, вироби 3 деревини та машини та обладнання.

Доцільно надалі нарощувати регіональний експорт і при цьому дбати не лише про збільшення його обсягів. Високий рівень імпортозалежності та значна технологічна відсталість виробничо-промислового комплексу потребують належну увагу приділити створенню довгострокових конкурентних переваг, стабільному розширенню та якісному поліпшенню на їх основі можливостей регіону. Необхідно створити умови для запровадження інновацій на машинобудівних підприємствах, залучити інвестиції для розвитку діючих і відкриття нових промислових об'єктів.

Світові ринки, зокрема ринки країн $Є С$, є досить привабливими для вітчизняних підприємств не лише з точки зору обсягу платоспроможного попиту, але й з точки зору стимулів вдосконалення матеріально-технічної, виробничої бази, підвищення конкурентоздатності продукції через дотримання високих європейських стандартів щодо якості продукції.

Досвід показав, що успішними експортерами у області є потужні виробники. Малий і середній бізнес потребує окрім інформаційної та консультативної допомоги, яка надається місцевими органами виконавчої влади, ефективних заходів щодо фінансової підтримки держави.

Окрім постійних заходів, які здійснюються для покращення ситуації, більшої уваги з боку держави та органів влади вимагають заходи, які потребують додаткового фінансування та зміни законодавства. До них можна віднести такі як:

- вдосконалення законодавчо-нормативного регулювання митних процедур та системи оподаткування експортно-імпортних операцій; 

імпортуються;

- переорієнтація вітчизняних виробників на виробництво товарів-аналогів, що інтелектуальних послуг;

- впровадження нових досягнень науки та техніки у виробничі процеси з метою модернізації виробничих потужностей для випуску експортної продукції;

- сприяння впровадженню міжнародних стандартів якості продукції та ін.

\section{СПИСОК ВИКОРИСТАНИХ ДЖЕРЕЛ}

1. Денисюк О. М. Зовнішня торгівля Вінницької області: сучасний стан та потенційні шляхи розвитку. Ефективна економіка. 2015. №. 11. URL: http://www.economy.nayka.com.ua/?op=1\&z=4479

2. Бурлака Н. I. Сучасний стан та перспективи розвитку експортної діяльності Вінницької області. Продовольчі ресурси. 2017. №. 9. С. 26-32.

3. Томчук О. В., Полеся В. М. Сучасний стан та шляхи розвитку зовнішньоекономічної діяльності у Вінницькій області. Економіка. Фінанси. Менеджмент: актуальні питання науки і практики. 2017. №. 6. С. 116-132.

4. Красняк О.П., Курило Н.Ф. Удосконалення системи управління зовнішньоекономічною діяльністю підприємств Вінницької області. Ефективна економіка. 2018. № 11. URL: http://www.economy.nayka.com.ua/?op=1\&z=6678

5. Савченко M. В., Витяганець I. М. Підвищення міжнародної конкурентоспроможності Вінницької області в умовах євроінтеграції. Економічний вісник Донбасу. 2020. №. 2 (60). С. 67-77.

6. Торговельне співробітництво Вінниччини з країнами Європейського Союзу. URL: $\quad$ http://www.vin.gov.ua/invest/mizhnarodne-spivrobitnytstvo/9158-torhovelnespivrobitnytstvo-vinnychchyny-z-krainamy-yevropeiskoho-soiuzu

7. Головне управління статистики у Вінницькій області. URL: https://vn.ukrstat.gov.ua/

8. Вінниччина - перлина Поділля - Аналітична довідка. URL: http://vin.gov.ua/bilshe/region/vinnychchyna-perlyna-podillia?showall=\&amp;start=1

\section{REFERENCES}

1. Denysiuk O. M. (2015) Zovnishnia torhivlia Vinnytskoi oblasti: suchasnyi stan ta potentsiini shliakhy rozvytku. Efektyvna ekonomika. 11. Available at: http://www.economy.nayka.com.ua/?op=1\&z=4479

2. Burlaka N. I. (2017) Suchasnyi stan ta perspektyvy rozvytku eksportnoi diialnosti Vinnytskoi oblasti. Prodovolchi resursy. 9. S. 26-32.

3. Tomchuk O. V., Polesia V. M. (2017). Suchasnyi stan ta shliakhy rozvytku zovnishnoekonomichnoi diialnosti u Vinnytskii oblasti. Ekonomika. Finansy. Menedzhment: aktualni pytannia nauky i praktyky. 6. S. 116-132.

4. Krasniak O.P., Kurylo N.F. (2018) Udoskonalennia systemy upravlinnia zovnishnoekonomichnoiu diialnistiu pidpryiemstv Vinnytskoi oblasti. Ефективна економіка. 11 Available at: http://www.economy.nayka.com.ua/?op=1\&z=6678

5. Savchenko M. V., Vytiahanets I. M. (2020) Pidvyshchennia mizhnarodnoi konkurentospromozhnosti Vinnytskoi oblasti v umovakh yevrointehratsii. Ekonomichnyi visnyk Donbasu. 2 (60). C. 67-77. 
6. Torhovelne spivrobitnytstvo Vinnychchyny z krainamy Yevropeiskoho Soiuzu. Available at: http://www.vin.gov.ua/invest/mizhnarodne-spivrobitnytstvo/9158-torhovelnespivrobitnytstvo-vinnychchyny-z-krainamy-yevropeiskoho-soiuzu

7. Holovne upravlinnia statystyky u Vinnytskii oblasti. Available at: https://vn.ukrstat.gov.ua/

8. Vinnychchyna - perlyna Podillia - Analitychna dovidka. Available at: http://vin.gov.ua/bilshe/region/vinnychchyna-perlyna-podillia?showall=\&amp;start=1

\section{Мережко В.H. \\ ТЕНДЕНЦИИ РАЗВИТИЯ ВНЕШНЕТОРГОВОЙ ДЕЯТЕЛЬНОСТИ ВИННИЦКОЙ ОБЛАСТИ}

В работе проводится анализ тенденций развития внешнеторговой деятельности Винницкой области. В основе анализа лежит исследование динамики показателей внешнеторговой деятельности Винницкой области за 2018 - 2020 года и за первое полугодие 2021 года. Для Винницкой области характерны восходящие тенденции роста экспорта, сокращение импорта товаров и услуг, положительное сальдо внешнеторгового оборота. В исследовании было обнаружено, что импорт товаров обеспечивает наполнение рынка Винницкой области дефицитными товарами; доступом к дешевым и качественным готовых изделий, сырьевых материалов, узлов и комплектующих деталей. Среди наиболее крупных экспортеров-партнеров Винницкой области в 2020 году были Китай (13,1\% общих объемов экспорта), Польша - 9,8\%, Индии - 6,1\% и Румыния - 5,2\%. Отличие динамики экспорта и импорта в том, что рынки экспортных потоков ежегодно меняются в зависимости от конъюнктуры рынков товаров, а рынки импорта товаров более стабильные и в течение 2018-2020 годов Германия, Польша, Китай, США и Румыния сохранили свои позиции в рейтинге стран импортёров. Субъекты хозяйствования Винницкого региона больше всего экспортируют продукцию животноводства и растениеводства, продукты пищевой промышленности. Такая товарная структура экспорта обусловлена мощным потенциалом региона в области АПК. В исследовании было отмечено, что сокращение импорта наземного транспорта в 2020 году, а также электрических и механических машин в 2019-2020 годах не является следствием расширения отечественного высокотехнологичного производства, а лишь свидетельствует уязвимость экономики государства и области к внешним воздействиям.

Ключевые слова: внешнеэкономическая деятельность, экспорт, импорт, Винницкая область, внешнеторговая деятельность, международная конкурентоспособность региона.

\section{Merezhko V. \\ TRENDS OF DEVELOPMENT OF FOREIGN TRADE ACTIVITY OF VINNITSA REGION}

The paper analyzes the development trends of foreign trade Vinnytsia region. The analysis is based on a study of the dynamics of foreign trade performance of Vinnytsia region for 2018 - 2020 and for the first half of 2021. Vinnytsia region is characterized by upward trends in export growth, reduction of imports of goods and services, a positive balance of foreign trade. The study found that the import of goods provides the market of Vinnytsia region with scarce goods; access to cheap and high-quality finished products, raw materials, components and parts. Among the most significant exporting partners of Vinnytsia region in 2020 were China (13.1\% of total exports), Poland $-9.8 \%$, India $-6.1 \%$ and Romania $-5.2 \%$. 
The difference between the dynamics of exports and imports is that export flow markets change annually depending on the situation of commodity markets, and commodity import markets are more stable and during 2018-2020 Germany, Poland, China, USA and Romania maintained their positions in the ranking of countries -importers. Entities of the Vinnytsia region mostly export livestock and crop products, food industry products. This commodity structure of exports is due to the strong potential of the region in the field of agriculture. The study noted that the reduction in imports of land transport in 2020, as well as electric and mechanical machines in 2019-2020 is not a consequence of the expansion of domestic hightech production, but only indicates the vulnerability of the economy and the region to external influences.

Keywords: foreign economic activity, export, import, Vinnytsia region, foreign trade activity, international competitiveness of the region. 